\title{
Écriture Feminine and the Poetry of Langston Hughes
}

\author{
--Shruti Das \\ Post Graduate Department of English, \\ Associate Director, Centre for Canadian Studies \\ Berhampur University, \\ Berhampur, Odisha, India \\ Email: drshrutidas@gmail.com
}

https://doi.org/10.3126/litstud.v34i01.39540

\section{Abstract}

This paper attempts to locate Hughes's poetic diction as Ecriture feminine since like feminist poetry the diction of his poetry is rebellious and questions the hierarchical structure of society where White people hold more power and promote the idea of racial superiority. His desire to express the angst of the Blacks finds currency in the definition and explication of feminine writing. The focus of this paper will be on analysis of the poetry of Langston Hughes in the light of ecriture feminine in order to show how Hughes counters hegemony's repressive rhetoric, challenges the loss of agency through the language of the dominant class and recreates another symbolic order.

Keywords: Langston Hughes, Revolution, Subjectivity, Ecriture Feminine, Black Experience

\section{Introduction}

Langston Hughes(1902-1967) was one of the central figures of the Harlem Renaissance of the 1920s. During the second decade of the twentieth century he ideologically joined socially conscious poets and writers like Stienbeck, Sandburg, Carlos Bulosan and John Dos Passos in subverting American high ideals and exposing the American reality for American Indians, African-Americans, immigrants and other oppressed people living in the margins of American society. He was known as "the poet laureate of the Negro race" for writing about the culture of the African Americans, of the jazz and the blues but his revolutionary voice stating the historical subjectivity of his race wasdeliberately ignored by his editors and publishers during his life time.Today, when racism is raising its ugly head again, it has become pertinent to remember and discuss the works of this important writer of the Harlem Renaissance whose rebellious voice is as important in the present circumstances as it was almost a century ago. Hughes's poetry is pithy, powerful, commanding and capable of expressing the voices from the margins in spite of hegemony's repressive rhetoric and incessant attempts to manipulate, suppress and 
obscure it. His poetry is simple and expresses the African-American experiences, diversities of thought and emotions of his people and dreams that he saw common to African-Americans in particular and deprived human beings in general. Hughes has written widely about "coloured cosmopolitanism" describing the pain of the oppressed of the world as a shared reality of his African-American condition. His desire to express the angst of the Blacks finds currency in the definition and explication of feminine writingby Michele Montrelay, for whom "desire is the prerequisite for symbolisation, and, she suggests, can only be satisfied in language. A feminine writing, Montrelay stresses, is thus one in which the writer, and hence the reader - instead of attempting to (re)create the (lost) object in words - plays with and enjoys the pleasures of the signifying procedure itself"' (Sellers 134). This paper attempts to analyse the poetry of Langston Hughes in the light of ecriture feminine in order to show how Hughes counters hegemony's repressive rhetoric and challenges the loss of agency through the language of the dominant class and recreates another symbolic order.

Hughes's poetry depicts the realities of American life and racially coloured language. Most of his poems are about the plight of the AfricanAmericans under the repressive forces of racism. But his editors during his lifetime looked at it from their own perspective. For them "his revolutionary prose and poetry represented an aberration, an isolated phase of his early career." Contrary to what the editors of Hughes said, his radical writings "were not a product only of his early career .... Many had appeared in print by 1940, by which time he was the established author of seven poetry collections, a novel, a juvenile, a volume of short stories, a Broadway play, an autobiography, and the recipient of numerous literary prizes. Some of his most radical works were written during the same period when his popular works appeared" (Berry xi). Hughes's revolutionary work pointed to the discrimination and cruelty of the Americans towards the African Americans which was considered at the time to be insignificant, very much like the treatment meted out to most feminist writing. His critique of hierarchy and social discrepancies and apartheid was overlooked, not only by his editors but alsoby his critics who attributed his revolutionary writing to a passing phase in his literary career and concentrated more on other facets of his writing.Even Harold Bloom in his "Introduction" toBloom's Modern Critical Views: Langston Hughes - New Edition (2008), much after the death of Hughes, derides his work as insignificant when measured in the literature written by the White writers like Whitman and Sandburg. He comments that Hughes's poetry is anchored on "Folk traditions ranging from blues to spiritualsto jazz songs to work chants to many other modes..., but his poems on the whole do not compare adequately to the bestinstances of those cultural models" (1). 
Bloom is typically dismissive about Hughes's work which he thinks are mere social and political considerations and not masterpieces of literature. He writes:

Social and political considerations, which doubtless will achieve somehistorical continuity, will provide something of an audience for Hughes's poetry.His first autobiography, The Big Sea, may be his most lasting single book, though its aesthetic values are very mixed. Rereading it, plus his second autobiography,I Wonder as I Wander, his Selected Poems, and The Langston Hughes Reader, I come to the sad conclusion that Hughes's principal work was his life, which is to say his literary career. (1-2)

Undaunted by criticism from the American academic elites Hughes continued writing poetry and inscribing the experiences of pain and indignity of the African Americans in his poetry. For him writing poetry had become a sacred commitment. Arnold Rampersad notes in his Introduction to The Collected Works of Langston Hughes (1995) that "while [Hughes] wished to write no verse that was beyond the ability of the masses of people to understand, his poetry, in common with that of other committed writers, is replete with allusions that must be respected and understood if it is to be properly appreciated. To respect Hughes's work, above all one must respect the African-American people and their culture, as well as the American people in general and their national culture" (5). Rampersad's comment moves us from a mono-ocular view of Hughes's poetry to that which this paper is attempting to project. This paper attempts to locate Hughes's poetic diction as Ecriture feminine since like feminist poetry the diction of his poetry is rebellious and questions the hierarchical structure of society where White people hold more power and promote the idea of racial superiority.

\section{Langston Hughes and Ecriture Feminine}

Hughes's poetry crosses the boundary of the ordinary and stereotypical depiction of black life located in the White centric vision of the Americans and narrate the complex and generally unnoticed aspects of black life. Hughes himself narrates the frustration of the African American artist in the face of white opacity (1-4). His poetry reflects the pain, the frustration and the trauma of having dreams that will never be fulfilled in the dominant White society of America. Hughes in his early poetry wrote about the domestic lives of the African American people and explored these themes as well as the pain of African American life sung to music like the blues and jazz. And his later poems were increasingly political tending towards Marxist ideology. He revolts against White domination of 
the blacks in America which accrues patriarchal dimensions. His poetry becomes subversive. In "I Look at the World" he writes:

I look then at the silly walls

Through dark eyes in a dark face-

And this is what I know:

That all these walls oppression builds

Will have to go!

I look at my own body

With eyes no longer blind-

And I see that my own hands can make

The world that's in my mind.

Then let us hurry, comrades,

The road to find.

Pain and an abject desire to win over pain, to move from the margins and be visible in the centre stage of American life is central to the writing of Hughes. His prophetic lines .".. all these walls oppression builds/Will have to go!" speak of rebellion of a people subjected to endless pain and frustration, repressed and marginalized over centuries. Body becomes an important site of performativity that has been subjugated and now demands agency.

Writing for Langston Hughes, like feminist writing, was an act of liberation, a means of addressing the crisis of African-American existence in racially polarized America. Bereft of agency and pinned to the margins of society, the racially repressed African-Americans sought liberation through their writings, their strategy much akin to the strategies of the feminist movement. This paper attempts to adopt the interest of the feminist wave of thought, that writing was act of liberation from the anxieties and repression, and apply them to Langston Hughes's writing which is bound to the psychological ideas of blackness as perceived by both the African Americans and the patriarchal White and thereby widen the scope of ecriture feminine. Set against the background of hatred and discrimination, Hughes work is vastly subversive expressing the desires and passions of the African Americans very much in line with the feminist thoughts of Teresa de Lauretis, who says that "the notion of experience in relation both to social-material practices and to theformation and processes of subjectivity is a feminist concept, not a poststructuralist tone" (260).Analyzing the works of Hughes in the framework of feminist theory will be appropriate since feminist theory is a "specific kind of political discourse: a critical and theoretical practice committed to the struggle against patriarchy and sexism [racism]" (parenthesis mine) (MoiThe Feminist Reader117).Faith Berry in the Introduction to her edited volume of Hughes' Writings of Social Protest states that Hughes has almost always, albeit unwillingly, written what his publishers and White 
audience have wanted him to write. Quite often he has suppressed his private self and integrity beneath layers of public self since he got the muchneeded economic stability from his writings.

Publishers who were enthusiastic about his jazz and blues poems would not touch poems such as "Good Morning Revolution." He could write revolutionarytracts, but he could not make a living from them, a situation that continually posed for him the choice between making a livelihood-and writing was his livelihood-or a sacrifice. Not to compromise his principles, he contributed some of the most incisive works he ever produced to small, obscure magazines and newspapers. (xii)

Hughes's position was rather like the political position of Richard Wright, whose "willingness to speak as Americans would have him speak, as the stranger. He speaks as the outsider whose challenge to American culture can be absorbed (even if it is to be acted upon rather than deflected) because it is a challenge from outside" (Budick 42). But Faith Berry's volume of Hughes's collected works contains those militant, revolutionary pieces of social protest written by him over thirty-two years which he had deliberately back grounded. Faith Berry notes,

... the social and political ideas [Hughes] espoused during the 1930s are evident in his poetry as early as 1925 . They appear in his later writings, though he was by then reluctant to discuss such ideas publicly, especially on lecture tours. In the 1940s and thereafter, his income was as dependent upon public readings as upon published books, a major reason he did not anthologize works he was hesitant to read before an audience. Late in his career he attempted to publish a volume which eventually appeared posthumously as The Panther and the Lash (1967). (xii)

Vera Kutzinski admits that little has been explored about the multiplicity in the writings of Langston Hughes. She comments:

Clearly, in the terms of discourses on race, nationality, sexuality, and class that insist on fixed subject positions, Hughes's multiple lived and imagined truths are neither possible nor intelligible. Discerning these truths and fully grasping their strategic slipperiness requires us to tune our scholarly tools to the ideological and historical frequencies of the languages and discourses in which we constitute our own senses of identity, place, and belonging.(10) 
Bringing James Baldwin and Richard Wright into the context adds significance to the argument that African American writing serves to identify and then condemn the internal dynamics of American culture, wherein racism was the constant underlying note. "[T]he African American,though once literally a stranger in America and considered bymany Americans (including black Americans) still to be a strangerof sorts, constitutes as foundational an element in the constructionof that culture as the American white .... The African American, therefore, mustmake his fellow Americans see him not as a stranger, but as an American"(Budick42). Wright's Bigger Thomas, for Baldwin, is like Stowe's Uncle Tom "the incarnation of a [white, racist] myth."He feels Wright's novel omits "the relationship that Negroes bear to one another, that depth of involvement and unspoken recognition of shared experience which creates a way of life" (Budick 42). In this connection it is relevant to discuss what Derrida called the "femininity of writing." Susan Sellers explains:

Derrida stresses that this conceptual system operates in language only through ignoring and suppressing the way language actually works. He suggested that writing, more than speech, retains the knowledge of its creation, and he employs this knowledge to unravel the complex threads of a writer's strategy. He argued that writing's own differential structure incorporates meanings beyond those the writer intended, since the process of meaning entails gaps in which other possibilities can erupt beyond the writer's control, to contradict and challenge his purpose. This 'supplement', Derrida suggests, is what gives writing its other status, since writing always contains the (unconscious) knowledge of its formation, other meanings, and the potential for the reader to interpret the text in an other way. It is this other function that underlies Derrida's insistence on the femininity of writing, which, he argues, has the capacity to deconstruct the parameters of our conceptual system. (132)

The writings of James Baldwin, Richard Wright and Langston Hughes are examples of the unspoken and coded shared experience of the African Americans in a racialised America.Hughes's poetry retains the knowledge of its creation emanating from the angst of African American life and their struggle for dignified existence. "Our Land" is one such poem which deconstructs the concept of America as the land of plenty and a land of happiness stating that America is a land where "joy is wrong." We read "Ah, we should have a land of joy,/Of love and joy and wine and 
song,/And not this land where joy is wrong" (Rampersad 33).The meaning escapes from the writer's control and the reader notices the gap in intent that contradicts the glorified picture of America.

According to Elizabeth Grosz the project of ecriture feminine is concerned with the lived body, the body insofar as it is represented and used in specific ways in particular cultures. For the writers of ecriture feminine, "the body is neither brute nor passive but is interwoven with and constitutive of systems of meaning, signification, and representation." (18) She further argues that, "far from being an inert, passive, noncultural and ahistorical term, the body may be seen as the crucial term, the site of contestation, in a series of economic, political, sexual, and intellectual struggles" (19).Hughes's lines:
I look at my own body
With eyes no longer blind-
And I see that my own hands can make
The world that's in my mind.
Then let us hurry, comrades,
The road to find. (Poetry Foundation, no page)

from "I Look at the World" testify to this. The African American body has historically been a site of negative signifieds accepted passively by both the Whites and the Blacks alike. Langston Hughes's lines "I look at my own body/ With eyes no longer blind" is coming of age of African Americans who have now decided to reclaim agency and revolt against oppression.Redding in the "Foreword" to Langston Hughes, Good Morning Revolution writes that the "militant, revolutionary pieces [of writing] give expression to a vaunted, though still unattained, American ideal, and that their emotive characteristics communicate the wish, the hope, and the faith that were Langston Hughes's all along, and that, indeed, inspired and were the themes of nearly all he wrote- " ... nary a sign of a color line/For the Freedom Train will be yours and mine!"“ (x) (parenthesis mine). It is pertinent to note Helene Cixous's observation regarding the construction of "woman." She writes "Ifyou are woman, you will resemble ideal woman; and you will obey the imperatives that mark your line. You will channel your desires, you will address them where, how, and to whom it is proper. You will honour the laws" (qtd. in Sellers 71). Similarly, there were "substantial pressures on a black autobiographer in the USA to construct himself as a subject that would represent African Americans in just the right ways: as valued citizens and loyal patriots. Hughes faced this issue not just in one but in two autobiographies, The Big Sea (1940) and I Wonder As I Wander (1956)"(Kutzinski 15).

Susan Sellers discusses Lacan and explains that "since the boy, unlike the girl, possesses a physical equivalent of the phallus, the girl's 
relationship to the symbolic order is complicated in a way that the boy's is not. The fact that the girl has no means of representing within herself even her lack - she has no penis to embody the phallus that stands both for the lost object/(m)other and for the act of signifying this - places her in a problematic relation to the symbolic code since, Lacan suggested, she cannot herself figure within its order and thus only exists according to man's definition of her there" (72). The problematizing of the African American active participation and visibility in the symbolic code of American society gathers meaning and can be comprehended in the paradigm of oppression. The nullified African American can be substituted for the castrated female. In his poem "A Black Pierrot" Hughes writes:

\author{
I am a black Pierrot: \\ She did not love me, \\ So with my once gay-colored soul \\ Shrunken like a balloon without air, \\ I went forth in the morning \\ To seek a new brown love. (Rampersad 31)
}

The pierrot is a stock comic character in a French pantomime who has a sad face and is always rejected in love. Hughes's unrequited love for America and his dejection thereafter, when he is hopeless and emasculated, is expressed in this poem. His 'gay-coloured' or happy soul is like a shrunken balloon without air.

Unacknowledged and marginalised by the American society, which refuses to hear the voice of the African Americans, he turns to Africa to find signification. Similarly, in another poem he writes, "Hold fast to dreams/For when dreams go/Life is a barren field/Frozen with snow" (32) implying that life for African- Americans in America is like a barren field frozen with snow where their dreams are stifled. This experience is continued in his poem "Negro Ghetto." Hughes doesn't find any happy person in the ghetto, what he finds are the black faces who are imprisoned in a supposedly free land. He sees people with "The wind imprisoned in the flesh" and their "sun bound down by law." His heart goes out to these humble people who are resilient and keep moving like "water down the street" (137). Centuries of oppression have made the black people numb and the reality of their existence is negated, ignored or mocked by the dominant White Americans who expect absolute humility from the African-Americans. Elsewhere, in "To Certain Negro Leaders" Hughes writes,

Voices crying in the wilderness

At so much per word

From the white folks:

"Be meek and humble, 


\title{
All you niggers, \\ And do not cry \\ Too loud." (134)
}

The White people, Hughes points out, are apathetic to the cause of the African-American. They mute the protests of the Blacks and impose cultural silence on them.In "Tired" Hughes acknowledges cultural and personal fatigue and a dangerous resilience where the hopeless people who have been waiting "For the world to become good/And beautiful and kind?" are willing to "take a knife/ And cut the world in two - / And see what worms are eating/At the rind." (135). The marginalized "other" of the white world are signified by worms who are to beget the waste/rind thrown to them. The lack of being treated as equal human beings brings about a permanent and profound sense of loss which garners meaning in Helene Cixous's argument that the White people assume the inherently masculine status by encoding discrimination as lack in the other. She visualizes agency in encoding lived experience"through writing in ways thatwill enable us to view ourselves and the world differently. Cixousstresses the potential of a feminine writing to work through loss, which, she argues, will inevitably challenge the current structure ofself-other relations. She urges the feminine writer to (re)claim thelived experience which the (masculine) symbolic seeks to bar" (Sellers 134) . Hughes indeed attempts to reclaim the lived experience of the AfricanAmerican by challenging the self-other relation imposed by the Whites on the Blacks. In "Scottsborough" he boldly writes and subverts established cultural performativity:

\author{
8 BLACK BOYS IN A SOUTHERN JAIL. \\ WORLD, TURN PALE! \\ 8 black boys and one white lie. \\ Is it much to die? (Rampersad 142) \\ And in "White Man" his defiance is evident \\ Sure, I know you! \\ You're a White Man. \\ I'm a Negro. \\ You take all the best jobs \\ And leave us the garbage cans to empty and \\ The halls to clean. (Berry 5)
}

\section{Conclusion}

Hughes defended the importance of a distinctly Black art and criticized "this urge within the race toward whiteness, the desire to pour racial individuality into the mould of American standardization, and to be as little Negro and as much American as possible."(Slate 58) The 
meanings of the words in his poetry, stories and plays, change if viewed from the perspective of the African- American rather than the racist White American. Nico Slate rightly argues that,

Hughes's refusal to be seen as just an American artist entailed not just separation from the American nation but integration with oppressed peoples throughout the world. Hughes's global integration did not come primarily through his poems about the world. Rather, it was his most intimate poems about the Black experience that endowed Hughes with a global audience. It was that audience, ultimately, that rendered Hughes the leading poet of the colored world. Foreign readers globalized Hughes and drafted him into the cause of colored solidarity. They made his poems speak to their experience. (58)

Oppressed people, especially women created a language of their own as a reaction against patriarchal language, which they called "ecriture feminine." "The concept of ecriture feminine," says Toril Moi in her famous essay "I I am not a Woman Writer': About women, Literature and feminist Theory Today"(2008), "championed in France by writers and psychoanalysts like Helen Cixous and Luce Irigaray was a parallel development, more intimately bound to psychoanalytical ideas of femininity" (260). Since violence and racism were the reality of the African-American experience, Langston Hughes's poems are in a similar vein radical, expressing of his own reaction against the oppression suffered by the African-Americans in the language of the Americans. They are his opposition to the white opacity imposed upon the AfricanAmericans in every sphere of their existence and expressions of their ongoing inner struggle. Hughes poetic language remains within the symbolic order of the oppressor and creates the lived experience of the other. Thereby, it enacts what Julia Kristeva suggests in the context of feminine language: it bores from within "unsettling and challenging though never completely destroying - the structures of the symbolic" (Sellers 133-134) American language.

\section{Works Cited}

Berry, Faith. Ed. Langston Hughes, Good Morning Revolution: Uncollected Writings of Social Protest. Lawrence Hill and Company, 1973.

Bloom, Harold. Bloom's Modern Critical Views: Langston Hughes-New Edition. Infobase Publishing, 2008.

Budick, Emily Miller. Blacks and Jews in Literary Conversation. Cambridge University Press, 1998. 
de Lauretis, Teresa. Upping the Anti (sic) in Feminist Theory. Conflicts in Feminism. Ed. Marianne Hirsch and Evelyn Fox Keller. New York: Routledge, 1990. 255-70.

Grosz, Elizabeth. Volatile Bodies: Toward a Corporeal Feminism. Bloomington: Indiana UP, 1994.

Hughes, Langston. "The Negro artist and the racial mountain." The Langston Hughes Review 4.1 (1985): 1-4.

Kutzinski, Vera M. The Worlds of Langston Hughes: Modernism and Translation in the Americas. Cornell University Press, 2012

Moi, TorilThe Feminist Reader: Essays in Gender and the Politics of Literary Criticism.Eds. Catherine Besley and Jane Moore. Basil Blackwell, 1989. Pp.117

----. "II am not a Woman Writer': About women, Literature and feminist Theory Today"Feminist Theory.2008; 9(3): 259271.doi:10.1177/1464700108095850

Rampersad, Arnold and David Roessel. Eds. The Collected Poems of Langston Hughes. Vintage Classics, 1995.

Redding, Saunders."Foreword." Langston Hughes, Good Morning Revolution: Uncollected Writings of Social Protest. Ed. Faith Berry. Lawrence Hill and Company, 1973.

Sellers, Susan. Language and Sexual Difference: Feminist Writing in France.St. Martin's Press, 1991.

Slate, Nico. Langston Hughes and Race as Propaganda. The Prism of Race Palgrave Macmillan 2014 pp 57-84. 